\title{
THE OZONE WATER-LAND ENVIRONMENTAL TRANSITION STUDY \\ An Innovative Strategy for Understanding Chesapeake Bay Pollution Events
}

\author{
John T. Sullivan, Timothy Berkoff, Guillaume Gronoff, Travis Knepp, Margaret Pippin, \\ Danette Allen, Laurence Twigg, Robert Swap, Maria Tzortziou, Anne M. Thompson, \\ Ryan M. Stauffer, Glenn M. Wolfe, James Flynn, Sally E. Pusede, Laura M. Judd, \\ William Moore, Barry D. Baker, Jay Al-SaAdi, and Thomas J. McGee
}

The Ozone Water-Land Environmental Transition Study (OWLETS) is an enhanced observational strategy aimed at better understanding chemical forecasts and pollution transport within the Chesapeake Bay watershed.

M easurements of pollution have been historically difficult to obtain in regions of complex terrain and/or directly over bodies of water-for example, within the Chesapeake Bay watershed. This poses a challenge for air quality managers and scientists responsible for monitoring the air quality of approximately $40 \%$ of the total U.S. population living within 100 miles of the U.S. coast (www oceanservice.noaa.gov). This is also a challenge for responsible parties interested in inland and coastal water quality, aquatic biology, and biogeochemistry (Tzortziou et al. 2015).

Since coastal environments have traditionally been undersampled, these intersecting communities have relied largely on chemical simulations to provide guidance for understanding the creation and transport of toxic pollutants [such as ozone $\left(\mathrm{O}_{3}\right)$ ]. Currently, surface-level $\mathrm{O}_{3}$ is frequently simulated over bodies of water including the Chesapeake Bay in excess of current regulatory standards; ${ }^{1}$ however, traditional forecast verification does not exist over bodies of water. Although current space-based observations are provided daily, they provide limited information for near-surface pollution and cannot reliably capture the diurnal cycle of pollutants. Therefore, we present an intensive set of observations that have been strategically positioned to reduce uncertainties and improve understanding within complex coastlines, specifically within the Chesapeake Bay watershed.

Previous investigations into understanding pollution events at the land-water interface, particularly near major urban centers, have taken place in several U.S. regions with poor air quality. Examples of these are the Lake Michigan Ozone Study in 1991 (Dye et al. 1995; Shafran et al. 2000) and 2017 (www-air .larc.nasa.gov/missions/lmos/), the Texas Air Quality

\footnotetext{
${ }^{1}$ Beginning in 2015, an area is in nonattainment status if its $\mathrm{O}_{3}$ design value, that is, its 3-yr average of the fourth-highest maximum daily 8 -h-average mixing ratio (www3.epa.gov /airquality/greenbook/hdtc.html), is larger than or equal to 71 ppbv, as set forth by the EPA via the NAAQS.
} 
Study in 2000 (Daum et al. 2004), and the Great Salt Lake City Ozone Study in 2015 (Blaylock et al. 2017). Furthermore, in 2011, as part of the larger efforts to conduct intensive observations of air quality across different regions of the United States, Deriving Information on Surface Conditions from Column and Vertically Resolved Observations Relevant to Air Quality (DISCOVER-AQ) ${ }^{2}$ implemented the first of its four targeted field campaigns on the upper Chesapeake Bay region and surrounding urban Interstate 95 Baltimore, Maryland-Washington, D.C., corridor with coordinated airborne and ground-based observations.

Within each of these complex waterway investigations, and especially within the Chesapeake Bay, differences in emissions, mesoscale meteorology, cloud coverage, and deposition rates over the water as compared to nearby continental landmasses drive gradients in $\mathrm{O}_{3}$ and other pollutants (Goldberg et al. 2014). The Chesapeake Bay is impacted by traditional point sources (such as power plants), as well as mobile sources (such as automobiles and other transport vehicles). Although these have largely been sampled and modeled in many regions, the latter, specifically mobile sources associated with ship transport or personal watercraft, remain understudied. Recent

\footnotetext{
${ }^{2}$ In 2010, the NASA Earth Venture Suborbital Program selected the DISCOVER-AQ proposal to improve the use of satellites to monitor air quality for the benefits of humans and the environment (Crawford and Pickering 2014). The remaining DISCOVER-AQ investigations were focused on complex-terrain regions associated with poor air quality, specifically, the greater regions surrounding the Los Angeles basin (winter 2013), Houston, Texas (summer 2013), and Denver, Colorado (summer 2014).
}

Affiliations: Sullivan, Swap, Thompson, and McGee-NASA Goddard Space Flight Center, Greenbelt, Maryland; BerkofF, PIPPIN, Allen, AND AL-SAADI-NASA Langley Research Center, Hampton, Virginia; Gronoff AND KNEPP-NASA Langley Research Center, and Science Systems and Applications, Inc., Hampton, Virginia; TwIGG—NASA Goddard Space Flight Center, Greenbelt, and Science Systems and Applications, Inc., Lanham, Maryland; TzOrTziOu-Department of Earth and Atmospheric Sciences, City College of New York, New York, New York; StAuffer-NASA Goddard Space Flight Center, Greenbelt, and Universities Space Research Association, Columbia, Maryland; WolfE-NASA Goddard Space Flight Center, Greenbelt, and Joint Center for Earth Systems Technology, University of Maryland, Baltimore County, Baltimore, Maryland; FLYNN-College of Natural Sciences and Mathematics, University of Houston, Houston, Texas;

This article is licensed under a Creative Commons Attribution 4.0 license. work from Ring et al. (2018) indicated that a better understanding of ship-based emissions, including the vertical allocation of emissions, is key to improving the understanding of chemical simulations, particularly in the heavily trafficked Chesapeake Bay region.

As eastern U.S. vehicular and industrial emissions decrease because of more stringent policy efforts, why and how can sporadic high pollution episodes still occur? The collective results of the DISCOVER-AQ investigations (Loughner et al. 2011, 2014; Stauffer et al. 2015; Garner et al. 2015; Mazzuca et al. 2017) have partially answered this question. They have identified episodes in which light winds sweep and pool pollutants out over the water. As winds stall, sunlight rapidly increases smog levels, and in the afternoon hours, winds shift direction back to an onshore flow, bringing back pollutants to inland areas. This is collectively known as the bay-breeze (or sea-breeze) phenomenon.

Although DISCOVER-AQ provided several isolated case studies within the Chesapeake Bay, a signature of bay-breeze recirculation exacerbating air quality events has been identified in long-term data records. A recent climatology of Chesapeake Bay sites (including Baltimore, Maryland and Hampton, Virginia) identified these finescale meteorological circulation events and linked them to the causes of $\mathrm{O}_{3}$ exceedances (Stauffer and Thompson 2015). While quasi episodic, these small-scale meteorological/recirculation events cannot be ignored-they are one of the few remaining scenarios that can routinely lead to excessive surface pollution levels in coastal regions. Results from Goldberg et al. (2014) corroborate these findings and extend them with in situ measurements during a 10-day Chesapeake Bay research cruise in July 2011.

PUSEDE-Department of Environmental Sciences, University of Virginia, Charlottesville, Virginia; JUDD—NASA Langley Research Center, Hampton, Virginia, and Universities Space Research Association, Columbia, Maryland; Moore-School of Atmospheric and Planetary Sciences, Hampton University, Hampton, Virginia; BAKER-NOAA/Air Resources Laboratory, and Cooperative Institute for Climate and Satellites, University of Maryland, College Park, College Park, Maryland CORRESPONDING AUTHOR: John T. Sullivan, john.t.sullivan@nasa.gov

The abstract for this article can be found in this issue, following the table of contents.

DOI:I0.II75/BAMS-D-18-0025.I

In final form 23 August 2018

(C)2019 American Meteorological Society

For information regarding reuse of this content and general copyright information, consult the AMS Copyright Policy. 
It is no secret-current satellites are not able to reliably characterize $\mathrm{O}_{3}$ in the lowest layers of the atmosphere. However, observations are critically needed within this region to understand processes relevant to air quality and pollution transport. To address these fundamental science and policy questions relating to $\mathrm{O}_{3}$, ground-based remote sensing efforts from $\mathrm{O}_{3}$ lidar have been utilized in conjunction with balloonborne and surface sampling techniques. To ensure support of these efforts and leverage the existing framework of knowledge within the larger atmospheric community, an interagency network initiated by NASA, NOAA, and EPA in 2011 began, known as the Tropospheric Ozone Lidar Network (TOLNet). Charter lidar systems are affiliated with NASA GSFC, NASA LaRC, NASA Jet Propulsion Laboratory (JPL), NOAA Earth System Research Laboratory (ESRL), and the University of Alabama, Huntsville. An international collaboration with Environment and Climate Change Canada (ECCC; Strawbridge et al. 2017) has also been established, as well as a modeling component at NASA Ames Research
Center (ARC) and data archiving administered at NASA LaRC.

Ozone lidars within TOLNet provide accurate (mostly within 5\%-10\%; Sullivan et al. 2015b; Wang et al. 2017; Leblanc et al. 2018) observations under both daytime and nighttime conditions and generate consistent, long-term datasets. Most of the instruments are portable and have been deployed previously in air quality campaigns (other than OWLETS) in coordination with state and local agency's interests, such as the Fires, Asian, and Stratospheric TransportLas Vegas Ozone Study (FAST-LVOS) in coordination with Clark County, Nevada; Department of Air Quality and the California Baseline Ozone Transport Study (CABOTS) in coordination with the California Air Resources Board (CARB); and supplementary investigations with the Maryland Department of the Environment.

Over the last few years, TOLNet measurements have provided a unique representation of tropospheric processes relevant to: air quality (Sullivan et al. 2016; Senff et al. 2016; De Young et al. 2017), long-term tropospheric trends (Granados-Muñoz and Leblanc 2016), and diagnoses of chemical transport simulations (Johnson et al. 2016; Dreessen et al. 2016). TOLNet also aims to provide a greater understanding of complex physical processes influencing tropospheric $\mathrm{O}_{3}$ production and transport such as nocturnal low-level jets (Sullivan et al. 2017), the North American monsoon (Granados-Muñoz et al. 2017), and convective thunderstorms (Wang et al. 2013). Recent upper-altitude TOLNet observations have also been important in characterizing details of stratospheric air entering the troposphere (Sullivan et al. 2015c; Kuang et al. 2017; Langford et al. 2018) that can perturb air quality (Langford et al. 2017). Other recent efforts in addition to campaign contributions are aimed at using TOLNet observations to validate/evaluate current (TROPOMI) and future (TEMPO) satellite retrievals of tropospheric $\mathrm{O}_{3}$ (Johnson et al. 2018).

The TOLNet data are accessible online (www-air.larc.nasa.gov/missions /TOLNet/). Consulting with the instrument principal or coinvestigators before usage is highly encouraged.
Although direct overwater observations are historically sparse, these shipborne samples were consistently $10 \%-20 \%$ higher than the closest upwind ground sites.

In synthesizing the aforementioned land-water air quality investigations, results have revealed two common themes. It is imperative to comprehensively characterize 1) the differences in the vertical distribution of pollutants directly over bodies of water as compared to those on continental landmasses and 2) the underlying chemical and meteorological processes that will lead to more accurate simulations of regional air quality. Therefore, the purpose of this paper is to describe the Ozone Water-Land Environmental Transition Study (OWLETS) and summarize key findings. The paper describes its deliberate approach to both advance upon and leverage off of the foundation provided by previous campaigns such as DISCOVER-AQ to enhance the understanding of the physical and chemical complexity of the water-land transition around the Chesapeake Bay, especially for improved air quality management. The strategy presented, which is a synergistic approach with multiple research networks, also provides a paradigm for future studies of the evolution of pollution events in coastal regions.

Previous land-water interface measurement efforts have largely relied on conventional in situ sampling via trace-gas analyzers and tethered and/or free-flying balloonborne systems to assess $\mathrm{O}_{3}$ variability and structure. While useful, these measurements provide a limited view of $\mathrm{O}_{3}$. Therefore, it is critical to have continuous vertical profiles of $\mathrm{O}_{3}$ and its precursors over both land and water, in concert with balloonborne, airborne, and surface samples, to more fully understand $\mathrm{O}_{3}$ dynamics and to provide verification for air quality forecasts and model simulations performed for air quality planning. With a recent emphasis on profiling capabilities, the National Aeronautics and Space Administration (NASA) TOLNet has been providing a more complete diurnal, vertical, and spatial understanding of complex Chesapeake Bay pollution events. These coordinated observations with a suite of additional sensors and platforms within the Chesapeake Bay are discussed below.

In looking toward the future, we expect these observations will be used to more fully characterize chemical 
transport simulations that can be used to evaluate future space-based geostationary air quality instruments, such as NASA's Tropospheric Emissions: Monitoring of Pollution (TEMPO) and the Korean Space Agency's Geostationary Environmental Monitoring Spectrometer (GEMS), and current polar-orbiting satellites, such as the European Space Agency (ESA)'s Sentinel-5 Precursor Tropospheric Monitoring Instrument (TROPOMI). Thus, this campaign serves as an "international TEMPO/ GEMS/TROPOMI validation prototype" within complex terrain and the first known direct measurements of synchronous and nearly continuous vertical profiles of $\mathrm{O}_{3}$ directly over water and over land.

OWLETS. To provide a unique platform of key observations to the air quality and scientific communities, the Ozone Water-Land Environmental Transition Study (OWLETS) ${ }^{3}$ was supported by the 2017 NASA Science Innovation Fund (SIF). ${ }^{4}$ As part of the 30-day investigation (from 5 July to 3 August 2017) conducted within the Tidewater region of the Chesapeake Bay, two research sites ${ }^{5}$ were established to provide synchronous vertical measurements of meteorology and pollutants directly over water [Chesapeake Bay Bridge Tunnel (CBBT)] and over land/continental [Langley Research Center (LaRC); see Fig. 1]. In combination with mobile (airborne, shipborne, and vehicular) observations connecting the two sites, pollutant gradients were directly observed and used to better understand the underlying fundamental processes occurring at the land-water interface.

The research sites were integrated with a combination of remote sensing (profilers), surface analyzing, passive, and balloonborne instrumentation (see Table 1). To better characterize profiles of $\mathrm{O}_{3}$ at both sites, synchronous measurements from two TOLNet $\mathrm{O}_{3}$ lidars were deployed - the NASA Goddard Space Flight Center (GSFC) Tropospheric Ozone (TROPOZ) Differential Absorption Lidar (DIAL; Sullivan et al. 2014, 2015a) and NASA LaRC Mobile Ozone Lidar (LMOL; De Young et al. 2017; Farris et al. 2018). To add more chemical and meteorological information, both sites incorporated synchronous (mostly within $10 \mathrm{~min}$ of each other) ozonesonde launches and continuous aerosol profiling with ground-based ceilometers. Passive trace-gas total-column amounts of $\mathrm{O}_{3}$ and nitrogen

${ }^{3}$ A NASA Earth feature with a more detailed summary of daily operations can be found online (www.nasa.gov/feature/langley /nasa-chesapeake-bay-study-to-help-improve-air-quality-forecasts).

${ }^{4}$ The SIF invests in highly innovative, exploratory, and high-risk-high-return scientific research, which is intended to promote science breakthroughs that demonstrate innovation (especially across NASA centers) and foster early-career scientists.

${ }^{5}$ The Chemistry and Physics of the Atmospheric Boundary Layer Experiment (CAPABLE; Martins et al. 2012; Knepp et al. 2015) site at NASA LaRC was used as the continental site, while the third island of the CBBT was used for direct overwater measurements.

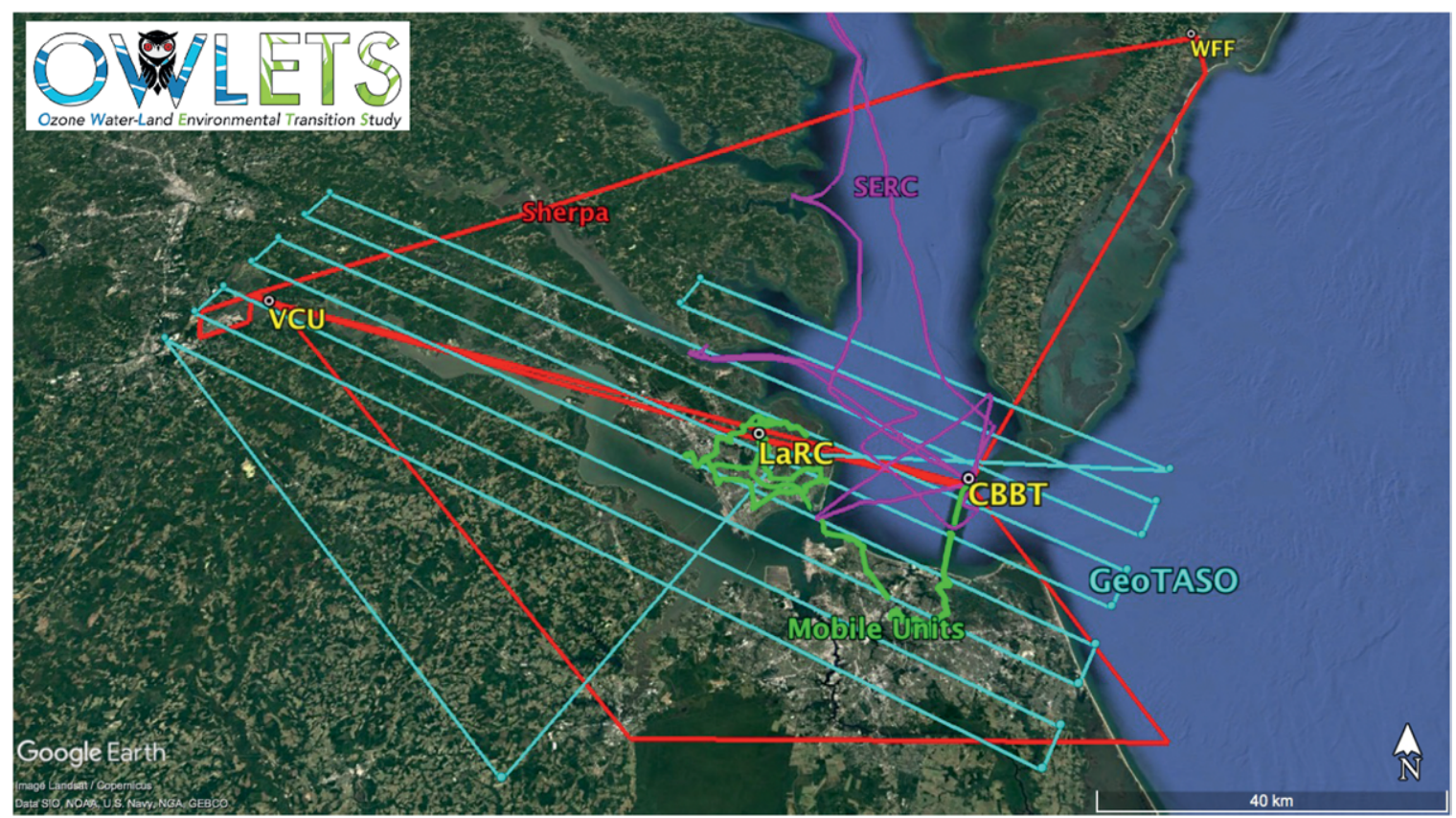

FIG. I. Overview of OWLETS ground sites, mobile unit pathways, research cruise routes, and aircraft sorties. 
dioxide $\left(\mathrm{NO}_{2}\right)$ and aerosol optical properties were provided at key sites from the NASA GSFC Pandora (https://acd-ext.gsfc.nasa.gov/Projects/Pandora lindex.html) and Aerosol Robotic Network (AERONet; https://aeronet.gsfc.nasa.gov) projects, respectively.

As part of the innovation of OWLETS, focus was placed on utilizing small or lower-cost $\mathrm{O}_{3}$ sensors on multiple platforms to better characterize spatial and vertical variability of surface-level and aloft $\mathrm{O}_{3}$ while also evaluating sensor performance. Personal Ozone
Monitors (POMs; www.twobtech.com/pom-personal -ozone-monitor.html) were installed on unpersonned aerial vehicles (UAVs) and automobile platforms to provide mobile $\mathrm{O}_{3}$ information. Permanent static regulatory and/or research surface analyzers from the Virginia (VA) Department of Environmental Quality (DEQ) and/or NASA also provided nearly continuous surface- $\mathrm{O}_{3}$ information for the duration of OWLETS. Additional research sites (see Fig. 1) included Virginia Commonwealth University (VCU), Hampton

\begin{tabular}{|c|c|c|c|c|}
\hline Instrument & Product & Reference & Site(s)/platform & Participation dates \\
\hline $\begin{array}{l}\text { GSFC O lidar } \\
\text { (TROPOZ) }\end{array}$ & $\begin{array}{l}\text { Tropospheric } \mathrm{O}_{3} \\
\text { profiles }\end{array}$ & Sullivan et al. (2014) & LaRC & All \\
\hline $\mathrm{LaRC} \mathrm{O}_{3}$ lidar (LMOL) & $\begin{array}{l}\text { Tropospheric } \mathrm{O}_{3} \\
\text { profiles }\end{array}$ & De Young et al. (2017) & CBBT & All \\
\hline Ozonesondes & $\begin{array}{l}\text { Profiles of } \mathrm{O}_{3}, \mathrm{RH}, T \text {, } \\
\text { wind }\end{array}$ & Thompson et al. (20I5) & CBBT, LaRC & All \\
\hline Pandora spectrometer & $\begin{array}{l}\mathrm{NO}_{2} \text { and } \mathrm{O}_{3} \text { total } \\
\text { column }\end{array}$ & $\begin{array}{l}\text { Herman et al. (2009); } \\
\text { Tzortziou et al. (20I2) }\end{array}$ & $\begin{array}{l}\text { CBBT, LaRC, VCU, } \\
\text { R/V SERC, WFF }\end{array}$ & $\begin{array}{l}\text { All, except R/V SERC } \\
\text { only } 17-18 \mathrm{Jul}\end{array}$ \\
\hline $\begin{array}{l}\text { AERONET } \\
\text { photometer }\end{array}$ & $\begin{array}{l}\text { Aerosol optical } \\
\text { properties }\end{array}$ & $\begin{array}{l}\text { Holben et al. (1998); } \\
\text { https://aeronet.gsfc } \\
\text {.nasa.gov }\end{array}$ & $\begin{array}{l}\text { LaRC, CBBT, } \\
\text { Hampton U. }\end{array}$ & All \\
\hline Micropulse lidar & $\begin{array}{l}\text { Aerosol backscatter } \\
\text { profiles }\end{array}$ & $\begin{array}{l}\text { Berkoff et al. (2004); } \\
\text { https://mplnet.gsfc } \\
\text {.nasa.gov }\end{array}$ & Hampton U. & All \\
\hline GeoTASO & $\mathrm{NO}_{2}$ slant/total columns & Nowlan et al. (2016) & NASA UC-I 2 & 7-8 Jul \\
\hline \multirow{5}{*}{$\begin{array}{l}\text { Airborne in situ } \\
\text { payload }\end{array}$} & $\mathrm{CO}_{2}, \mathrm{H}_{2} \mathrm{O}, \mathrm{CH}_{4}$ & Wolfe et al. (20।8) & \multirow{5}{*}{ NASA C-23 Sherpa } & \multirow{5}{*}{ 19-20 Jul } \\
\hline & $\mathrm{HCHO}$ & St. Clair et al. (2017) & & \\
\hline & $\mathrm{NO}_{2}, \mathrm{NO}, \mathrm{O}_{3}$ & $\begin{array}{l}\text { Pollack et al. (20I0); } \\
\text { Ridley and Grahek } \\
\text { (1990); FEM designation } \\
\text { EQOA-04I0-190. }\end{array}$ & & \\
\hline & $\mathrm{CO}$ & www.lgrinc.com & & \\
\hline & VOCs & Barletta et al. (20I7) & & \\
\hline POM & $\mathrm{O}_{3}$ & www.twobtech.com/ & Mobile units, UAV & All \\
\hline Ceilometer (CL-5I) & $\begin{array}{l}\text { Aerosol backscatter } \\
\text { profiles }\end{array}$ & www.vaisala.fi & $\begin{array}{l}\text { CBBT, LaRC, VCU, } \\
\text { R/V SERC }\end{array}$ & $\begin{array}{l}\text { All, except R/V SERC } \\
\text { only } 17-18 \text { Jul }\end{array}$ \\
\hline \multirow{5}{*}{$\begin{array}{l}\text { Hampton Roads/ } \\
\text { Richmond regulatory } \\
\text { static monitors }\end{array}$} & $\mathrm{O}_{3}, \mathrm{SO}_{2}, \mathrm{CO}, \mathrm{NO}_{2}, \mathrm{O}_{3}$ & \multirow{5}{*}{$\begin{array}{l}\text { www.deq.virginia.gov; } \\
\mathrm{O}_{3} \text { and } \mathrm{NO}_{2} \text { research } \\
\text { analyzers provided by } \\
\text { NASA }\end{array}$} & $\begin{array}{l}\text { LaRC }{ }^{*+,} \text {, Shirley } \\
\text { Plantation }\end{array}$ & All \\
\hline & $\mathrm{O}_{3}, \mathrm{NO}_{2}$ & & $\begin{array}{l}\mathrm{CBBT}^{*,+}, \mathrm{R} / \mathrm{V} \text { SERC }{ }^{*+}, \\
\text { VLM*, TRO* }\end{array}$ & $\begin{array}{l}\text { All, except R/V SERC } \\
\text { only } 17-18 \text { Jul }\end{array}$ \\
\hline & $\mathrm{CO}, \mathrm{SO}_{2}, \mathrm{NO}_{2}$ & & Norfolk & All \\
\hline & $\mathrm{O}_{3}$ & & $\begin{array}{l}\text { Tidewater, Suffolk, } \\
\text { Hanover, Beach Road }\end{array}$ & All \\
\hline & $\mathrm{O}_{3}, \mathrm{SO}_{2}, \mathrm{CO}, \mathrm{PM}$ & & $\begin{array}{l}\text { Richmond (Math and } \\
\text { Science Center) }\end{array}$ & All \\
\hline
\end{tabular}


University (Hampton U.), Wallops Flight Facility (WFF), the Virginia Living Museum (VLM), and the National Oceanic and Atmospheric Administration (NOAA)/Tidewater Regional Office (TRO).

In coordination with OWLETS, measurements were conducted from the Smithsonian Environmental Research Center 41-ft $(12.5 \mathrm{~m})$ marine research vessel [Research Vessel (R/V) Smithsonian Environmental Research Center (SERC)] and NASA aircraft. The R/V $S E R C$ characterized atmospheric gradients within the lower Chesapeake Bay and in the transition from the upper- to lower-bay watershed, providing shipborne measurements of trace gases and aerosol backscatter profiles on 17 and 18 July (cruise path in Fig. 1). Instruments on R/V SERC included a Pandora spectrometer, in situ gas analyzers, and a ceilometer. Overpasses and spirals were performed from the NASA C-23 Sherpa (flight path in Fig. 1) on 19 and 20 July, carrying an in situ air quality payload (Table 1). The C-23 Sherpa flights were designed to provide validation for the ground sites and sampling of regional emissions. Remote sensing observations were also provided from the downward-looking Geostationary Trace Gas and Aerosol Spectrometer (GeoTASO; https://airbornescience .nasa.gov/content/GEO-TASO) on board the UC-12 King Air aircraft on 7 and 8 July to measure $\mathrm{NO}_{2}$ slant columns that can be used to infer local sources that may be influencing air quality (flight path in Fig. 1).

Summer interns were involved in nearly all aspects of OWLETS, significantly increasing available field observations and support for future analyses.

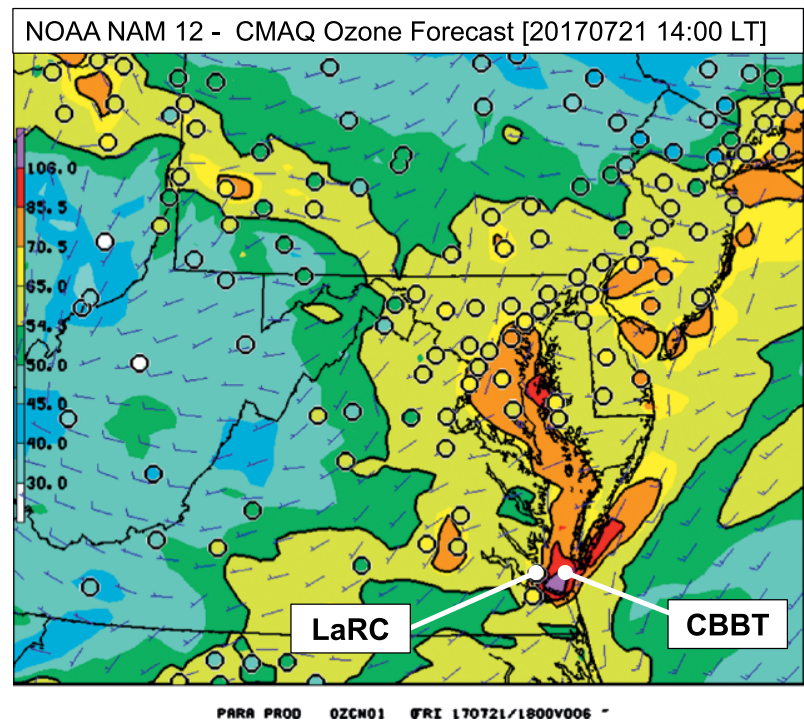

Fig. 2. NOAA CMAQ $\mathrm{O}_{3}$ forecast (from $0800 \mathrm{LT}$ ) and regional surface monitors (circles) for 1400 LT 21 Jul 2017. Color bar on the left shows ground-level I-h $\mathrm{O}_{3}$ (ppbv).
Specifically, undergraduate- and graduate-level interns were supported by the LaRC TEMPO student collaboration team, designed for TEMPO-related air quality research (http://tempo.si.edu/outreach .html). The interns contributed operational forecasting during the campaign, in situ $\mathrm{O}_{3}$ measurements from mobile cars, UAV operations, ozonesonde launches, and lidar operations. Additional intern involvement was further supported through the NASA Internship and Fellowship (NIFS) program, NASA Advanced Computing for Earth Sciences (ACES), the Hampton University Center for Atmospheric Research and Education (HU:CARE), and the NOAA Center for Earth System Sciences and Remote Sensing Technologies (CESSRST) internship programs. In summary, with a diverse group of state, federal, and university resources, 12 intensive measurement days in JulyAugust 2017 were conducted in the Chesapeake Bay region to investigate chemical transport and gradients directly at the land-water interface. The following section highlights the key OWLETS measurements and demonstrates a unique $\mathrm{O}_{3}$ verification dataset for chemical transport simulations/forecasts and for current and future satellite validation.

OWLETS KEY MEASUREMENTS. We present an intensive set of observations that have been strategically positioned to reduce uncertainties and improve understanding of pollutant transport within complex terrain, specifically within the Chesapeake Bay watershed. OWLETS utilized operational air quality forecasts from the NOAA National Air Quality Forecast Capability (NAQFC) ${ }^{6}$ to identify potential pollution episodes and guide intensive field measurements. Operational NAQFC forecasts for ground-level $\mathrm{O}_{3}$ are provided hourly at $12 \mathrm{-km}$ spatial resolution. The OWLETS sampling strategy also considered air quality forecasts from state agencies, such as VA DEQ and the Maryland Department of the

${ }^{6}$ The NAQFC numerical prediction system is operationally integrated on a National Centers for Environmental Prediction (NCEP) supercomputer, which utilizes the NOAA/EPA Community Multiscale Air Quality (CMAQ) model and is driven by the NOAA/NCEP North American Mesoscale Forecast System (NAM) numerical weather prediction model. NAQFC incorporates a compilation of National Weather Service (NWS) weather observations and current EPA emission inventories (Chai et al. 2013; Tong et al. 2015). Each day, there are four different predicting cycles, initialized at $0000,0600,1200$, and 1800 UTC, which use the newest meteorological fields available. The cycles starting at 0600 and 1200 UTC produce predictions for the next $48 \mathrm{~h}$. 
Environment (MDE), and global chemical transport models, such as the Realtime Air Quality Modeling System (RAQMS; http:// raqms-ops.ssec.wisc.edu) and the NASA Goddard Earth Observing System Model, version 5 (GEOS5; https://gmao.gsfc.nasa .gov/GEOS/). With this combination of forecasts, measurements were scheduled to maximize coverage in the several hours leading up to and after forecasted high- $\mathrm{O}_{3}$ episodes.

An example of a forecasted high- $\mathrm{O}_{3}$ episode from the NOAA NAQFC is shown in Fig. 2 for 1400 local time (LT) 21 July 2017. This forecast simulates a common summertime high-O $\mathrm{O}_{3}$ "bulls eye" feature centered over the water in the lower Chesapeake Bay region with nominally light synoptic forcing. This is associated with light southerly flow within the lower Chesapeake Bay and light southwesterly flow near LaRC, as depicted in the wind barbs in Fig. 2. For this day, forecasted peak $\mathrm{O}_{3}$ concentrations over the water were nearly $30 \%-60 \%$ larger than those forecasted over land, further moti-

vating the need for outfitting the CBBT site during OWLETS with intensive measurement capabilities to directly sample this simulated overwater $\mathrm{O}_{3}$ reservoir. Ground-based networks of surface monitoring sites are shown as circles in Fig. 2, indicating the NAQFC accurately reproduced a majority of the on-land hourly $\mathrm{O}_{3}$ concentrations during the forecast period. However, verification of the surface and profile concentrations of overwater pollution, boundary layer tracer transport, and return flows are needed. This is particularly true in the context of the meteorological conditions (such as the bay breeze) that may draw overwater pollutants back inland to negatively impact air quality conditions. wind direction.
GSFC TROPOZ (@LARC) 21-Jul-2017 06:00 to 21-Jul-2017 20:00

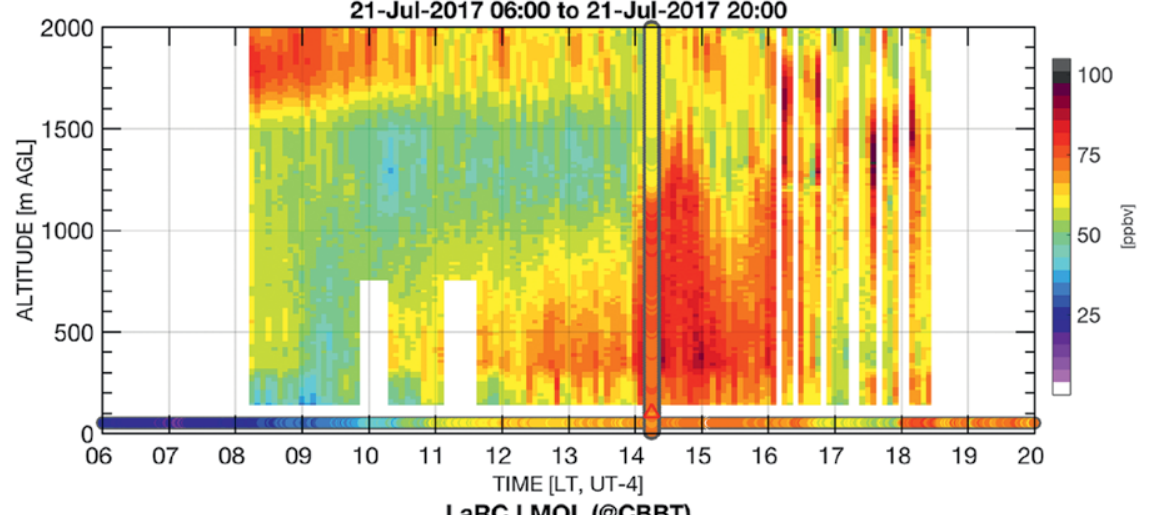

LaRC LMOL (@CBBT)

21-Jul-2017 06:00 to 21-Jul-2017 20:00
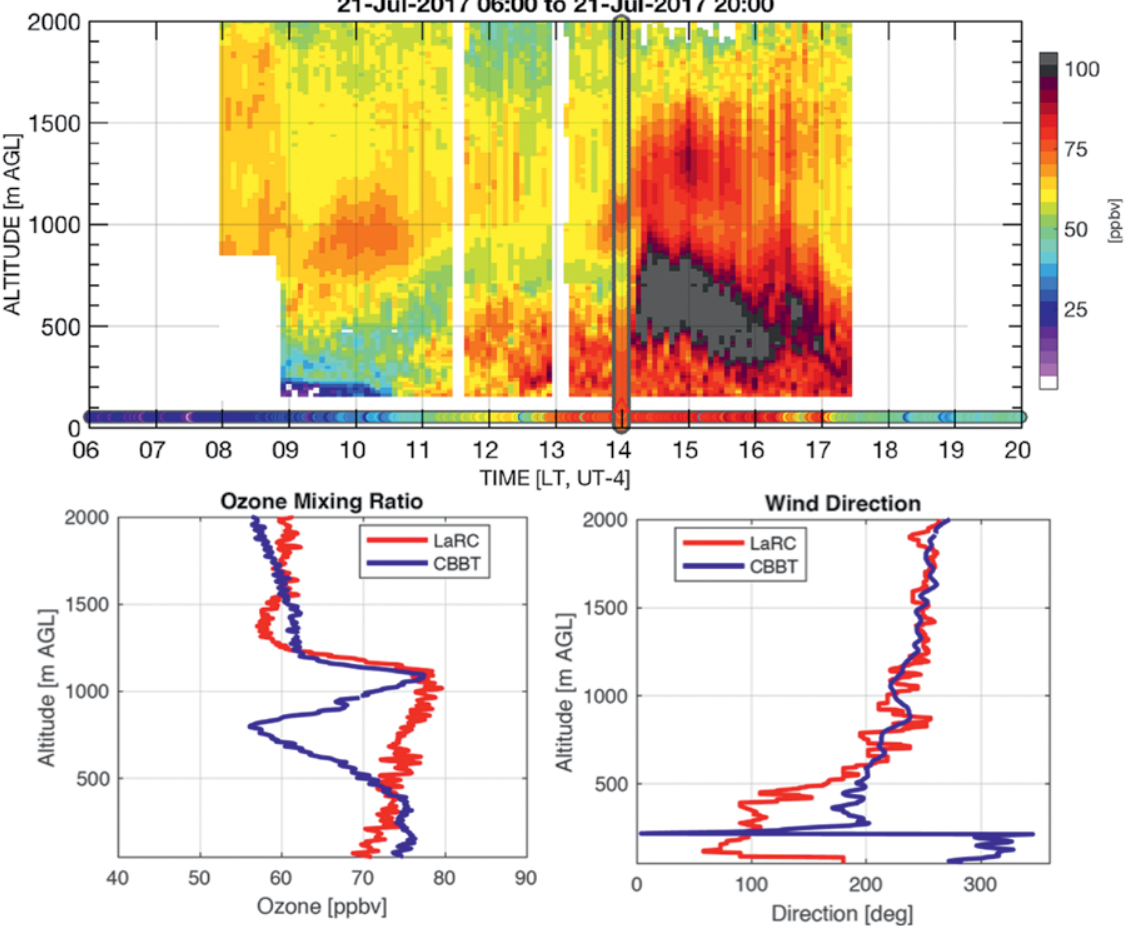

FIG. 3. Synchronous profiles of $\mathrm{O}_{3}$ from (top) the GSFC TROPOZ at NASA LaRC and (middle) the LaRC LMOL at CBBT from 0600 to 2000 LT 2I Jul for the first $2000 \mathrm{~m} \mathrm{AGL}$. (bottom) The sonde profile of (left) $O_{3}$ and (right)

Understanding aloft transport with tropospheric ozone lidar. During the intensive measurement days of OWLETS, TOLNet lidars measured profiles of $\mathrm{O}_{3}$ nearly continuously during peak pollution episodes in support of air quality forecast verification and aircraft-/ship-based observations. An example of the continuous TOLNet time series during the NAQFC forecast in Fig. 2, from 0600 to 2000 LT 21 July, is shown at 5-min temporal resolution for the first $2000 \mathrm{~m}$ (Fig. 3). The measurements are supplemented with a synchronized ozonesonde launch at each site (near 1400 LT) and in situ surface analyzers in the bottom of each lidar cross section. To generate these 
results, the GSFC and LaRC processing algorithms used identical vertical resolution and temporal averaging in order to accurately identify processes linked to geophysical and chemical gradients.

The measurements indicate the presence of residual $\mathrm{O}_{3}$ layering at the inland site (LaRC) above 1500 and $500 \mathrm{~m}$ in the marine environment (CBBT). From 1100 until 1400 LT, both sites indicate a similar con-

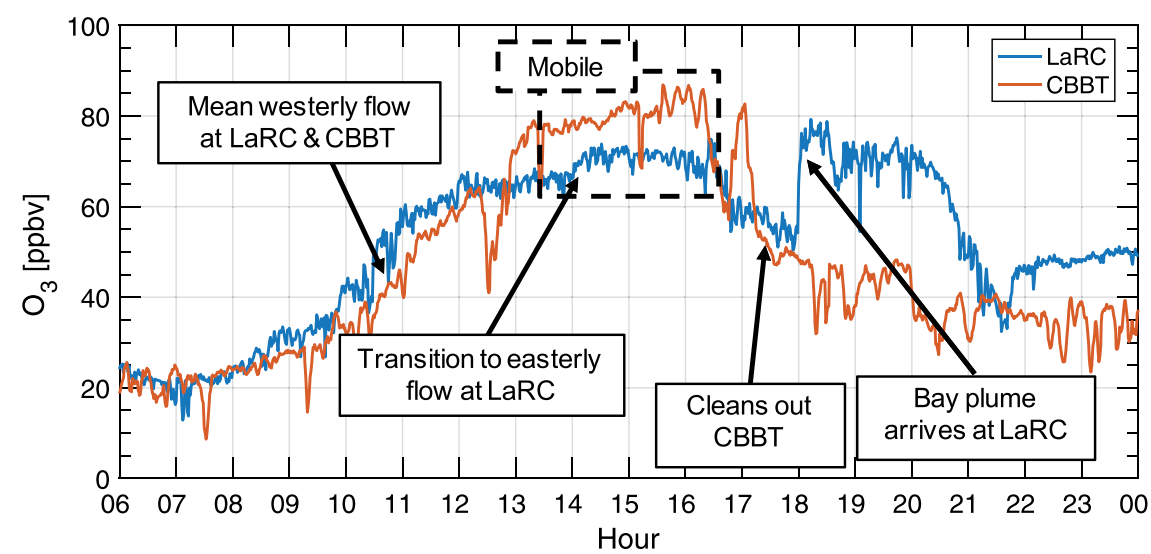

FIg. 4. Surface $O_{3}$ and flow description at LaRC and CBBT from 0600 to 2400 LT 2 I Jul. The dashed box indicates the timing of overlap with the mobile observations (Fig. 5). vective mixing-layer growth rate and depth of 700-800 $\mathrm{m}$ above ground level (AGL). However, just after $1400 \mathrm{LT}, \mathrm{O}_{3}$ concentrations at both sites increase from near 60-65 to 70-80 ppbv, and $\mathrm{O}_{3}$ is observed at heights toward $1200 \mathrm{~m}$ AGL. Abrupt changes in $\mathrm{O}_{3}$ profiles are linked to overall flow pattern changes. The wind direction profiles from the ozonesondes near 1400 LT (bottom panel of Fig. 3) indicate LaRC received easterly winds below $500 \mathrm{~m}$ - confirming a bay breeze was established. Winds at LaRC from 500 to $1200 \mathrm{~m}$ AGL continued with a mean westerly or southwesterly flow as earlier in the day.

In the marine environment at CBBT, lower-level (100-300 m AGL) winds are very light $\left(<1 \mathrm{~m} \mathrm{~s}^{-1}\right)$, indicating general stagnation in this altitude region over the lower Chesapeake Bay. With these lighter winds and aged local emissions transported out over the water throughout the morning, $\mathrm{O}_{3}$ concentrations increase quickly by midday. The LMOL TOLNet lidar (middle panel of Fig. 3) indicates the onset of the dirty air mass (peak concentrations $>120$ ppbv) at CBBT within the altitude range of 400-800 m AGL. From the sounding at 1400 LT (bottom panel of Fig. 3), this polluted air mass is associated with mostly southerly flow below $800 \mathrm{~m}$ and transitions to southwesterly flow above that. Although at $1400 \mathrm{LT}$, the LaRC site observes a well-mixed $\mathrm{O}_{3}$ profile up to $1200 \mathrm{~m} \mathrm{AGL}$, the changing wind directions with altitude at $\mathrm{CBBT}$ yields a complex $\mathrm{O}_{3}$ profile with near-surface values of $80 \mathrm{ppbv}$, decreasing rapidly to near $50 \mathrm{ppbv}$ at $800 \mathrm{~m} \mathrm{AGL}$, and then returning to near $75 \mathrm{ppbv}$ at $1200 \mathrm{~m}$ AGL.

Surface $\mathrm{O}_{3}$ from LaRC and CBBT (Fig. 4) is used to further quantify the transport of the higher- $\mathrm{O}_{3}$ plume from the lower Chesapeake Bay inland toward LaRC. Mean westerly flow throughout the region helps keep the $\mathrm{O}_{3}$ concentrations similar at both sites until 1200-1300 LT. As winds ease into stagnation at
$\mathrm{CBBT}$ and reverse to easterly at $\mathrm{LaRC}, \mathrm{O}_{3}$ remains between 80 and 90 ppbv for CBBT and between 70 and 75 ppbv for LaRC. By 1800 LT, CBBT observes concentrations near 40-50 ppbv, indicating much cleaner conditions than during the daytime period. However, as easterly flow continues to bring the polluted bay plume inland, the LaRC site abruptly increases in $\mathrm{O}_{3}$ to a maximum of near $80 \mathrm{ppbv}$ and remains above 70 ppbv until near 2100 LT. Although neither site observed an exceedance ${ }^{7}$ with the onset [maximum daily 8 -h average (MDA8) $\geq 71 \mathrm{ppbv]}$ of the U.S. Environmental Protection Agency (EPA) National Ambient Air Quality Standards (NAAQS), with the onset and late-night persistence of the bay breeze, the MDA8 value at LaRC (66 ppbv) finished higher than at CBBT (64 ppbv). Previous work has also shown the implications of bay-breeze-driven sustained high $\mathrm{O}_{3}$ values late into the evening at Edgewood, Maryland, in July 2011 (Stauffer et al. 2015). Although the NAQFC overestimated the hourly $\mathrm{O}_{3}$ concentrations at CBBT (forecast: $85-106$ ppbv; observed: 81 ppbv), it correctly forecasted the timing (1400 LT) of the peak conditions, indicating the chemical transport system is able to suitably forecast transport features associated with the bay breeze, such as lower-level flow reversals and onshore flows.

There are an additional 11 intensive days of measurements from the OWLETS campaign, which largely sample morning and afternoon convective boundary layer growth periods. Most of the remaining subsections provide further observations and context for the polluted conditions that persisted from 17 to 21 July 2017.

\footnotetext{
${ }^{7}$ See footnote 1 on page 291.
} 
Mobile in situ $\mathrm{O}_{3}$ sampling using automobiles and UAV. To meet the science innovation goals of providing a more comprehensive view of the horizontal and vertical variability of $\mathrm{O}_{3}$, OWLETS tested low-cost and reliable $\mathrm{POM}^{8}$ sensors (Table 1) that were integrated into mobile (vehicular and UAV) platforms. As shown in the left inset of Fig. 5, the POMs were adapted to attach to automobile windows and were able to sample while in transit or parked. Vehicle paths were chosen to include waypoints at strategic locations to sample away from heavy traffic emissions as well as to obtain data at various OWLETS static ground sites to provide cross-sensor validation observations. Their sampling geography was chosen to represent surface variability within the context of the TEMPO ${ }_{3}$ product nominal footprint (Fig. 5; $8.4 \mathrm{~km}$ north-south $\times 4.7 \mathrm{~km}$ eastwest at the center of domain; Zoogman et al. 2017).

Figure 5 highlights a period from 1320 to 1645 LT 21 July 2017, in which two vehicular platforms were deployed to provide novel verification information for the NAQFC-forecasted high- $\mathrm{O}_{3}$ episode at $1400 \mathrm{LT}$ (as shown in Fig. 2). The first vehicle remained near LaRC to sample continental $\mathrm{O}_{3}$ variability, while the second traveled south and eastward from LaRC to approach the CBBT site and the bull's-eye feature predicted in the forecast. The overall timing and context of these mobile sampling efforts is referred to in the dashed box from Fig. 4. While the first vehicle sampled $\mathrm{O}_{3}$ concentrations consistently within the 50-65-ppbv range at LaRC, the second vehicle sampled peak concentrations of 90-100 ppbv over the water on the CBBT. Furthermore,

${ }^{8}$ POM sensors have EPA Federal Equivalent Method (FEM) approval, National Institute of Standards and Technology (NIST) calibration traceability, and compact design $(0.1 \mathrm{~m} \times$ $0.07 \mathrm{~m} \times 0.04 \mathrm{~m}$ and $0.45 \mathrm{~kg}$ ). Each has a self-contained GPS tracking system, air sampling pump, data storage memory, and battery power supply. Precampaign characterization tests indicated calibration agreement $( \pm 2 \%)$ at $0.1 \mathrm{~Hz}$ (e.g., sampling every $10 \mathrm{~s}$ ), as compared to a calibration standard photometer. with these versatile and mobile sampling efforts, a nearly 20-ppbv spatial gradient in $\mathrm{O}_{3}$ was observed directly at the land-water interface. Since the mobile sampling was performed during the transition to easterly flow inland, the sensors are also able to help quantify the inland penetration depth of the polluted bay plume. The concentrations observed inland are between 75 and 85 ppbv, which corroborate those that are observed at LaRC 1-2 $\mathrm{h}$ later. This indicates the mobile observations were able to sample a critical bay-breeze transition region that contained remnants of the overwater high- $\mathrm{O}_{3}$ reservoir and the transport of higher concentrations moving inland and approaching the greater Hampton Roads populated areas. Future analyses of the mobile observations will be to investigate variability in $\mathrm{O}_{3}$ within individual satellite pixel size (such as TEMPO) and provide insights for future ground-site locations for satellite validation.

UAV platforms provided the unique ability to investigate near-range vertical and spatial $\mathrm{O}_{3}$ variability deemed too complicated (or expensive) for traditional large aircraft investigations. The UAV flights, which were supported by the LaRC Autonomy Incubator team and UAV Operations Office, were able to sample vertically to an altitude up to 100 and $200 \mathrm{~m}$ at LaRC and CBBT, respectively, and horizontally within visual range. Although sampling during

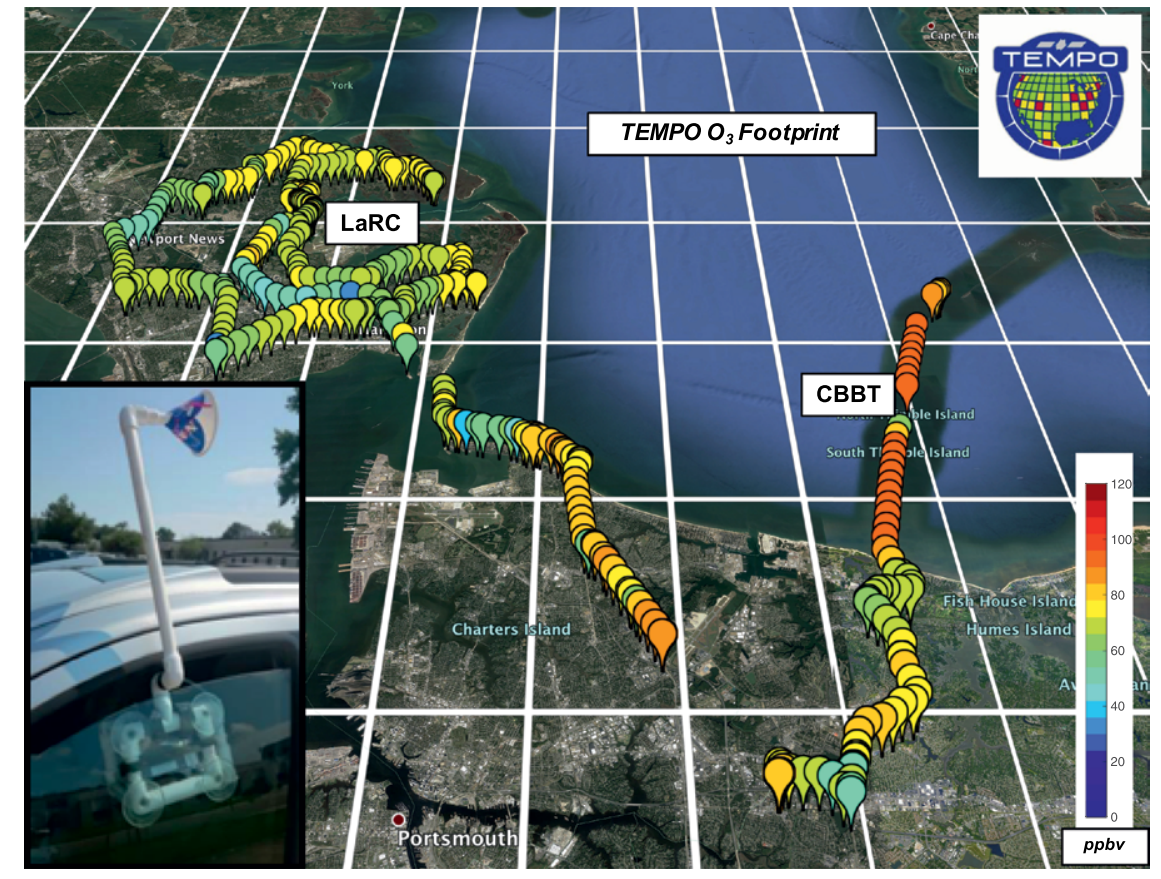

FIG. 5. The main image shows the POM mobile observations map on 21 Jul 2017 to better characterize spatial gradients within the OWLETS domain and the inset shows the mounting design. 


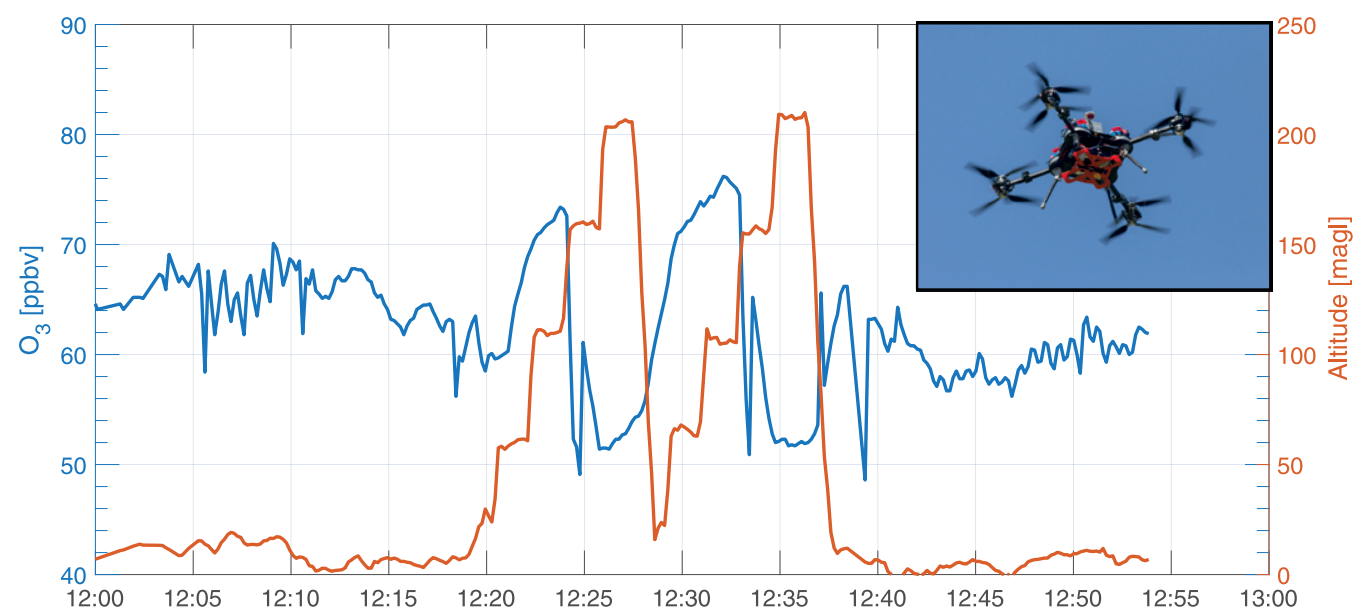

FIG. 6. The main plot shows the UAV sampling at the CBBT site for 2 Aug 2017. The inset shows the UAV platform.

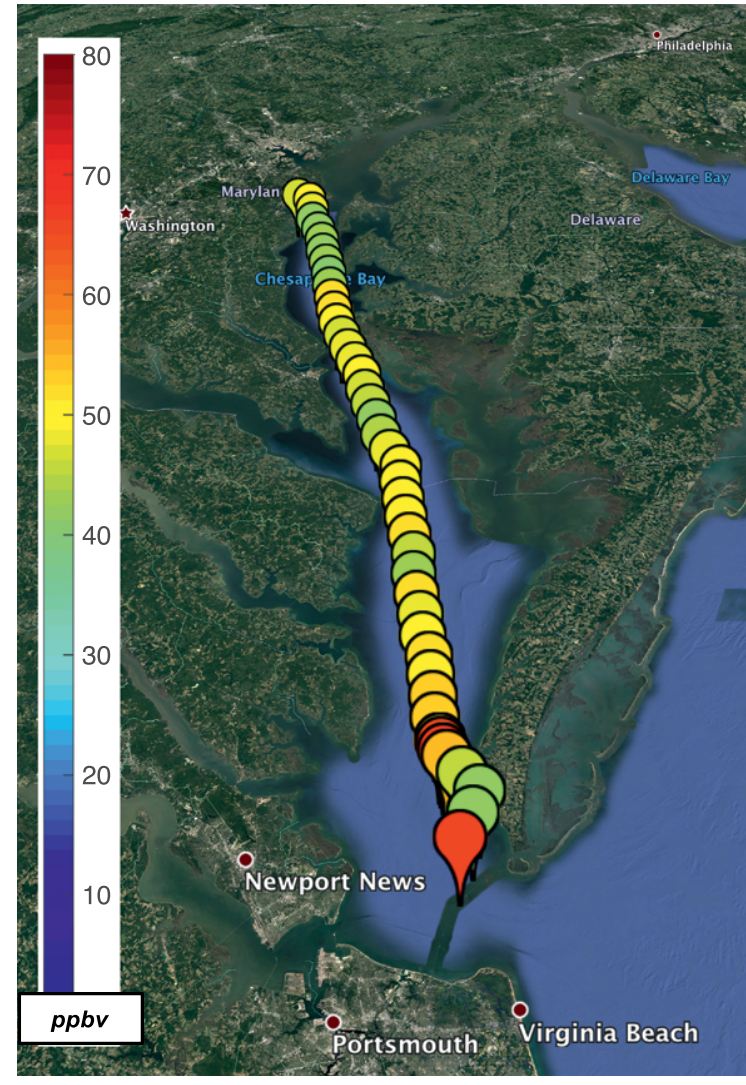

Fig. 7. In situ $\mathrm{O}_{3}$ during the R/V SERC transect on 17 Jul 2017. Peak $\mathrm{O}_{3}$ sampled near the CBBT site occurred near 1430 LT.

the late July episode was unavailable, we present UAV observations (Fig. 6) from 1200 to 1300 LT 2 August 2017 that provide context for the overall OWLETS objective of understanding the vertical profiles of pollution over the water.

Since large shipping vessels frequently passed between the third and fourth islands of the CBBT, the location served as an effective vantage point for directly sampling ship-based emissions. Cargo vessel emissions are mostly at or below 200 m AGL (Ring et al. 2018); therefore, UAV routes were designed to provide high-resolution observations within this altitude range. During two repeated transects in Fig. 6, the UAV remained at the surface level, sampling $\mathrm{O}_{3}$ concentrations between 60 and 65 ppbv. The UAV then ascended to an altitude of near $200 \mathrm{~m}$ in 50-m increments (hovering at each waypoint for $1 \mathrm{~min}$ ). As the UAV reached $100 \mathrm{~m}$ during this flight pattern at 1223 and $1233 \mathrm{LT} \mathrm{O}_{3}$ concentrations were sampled between 75 and $78 \mathrm{ppbv}$. Within $2 \mathrm{~min}$ of the 100-m sampling, the UAV reached $200 \mathrm{~m}$, and $\mathrm{O}_{3}$ concentrations were drastically reduced to $50-53 \mathrm{ppbv}$. With this type of direct OWLETS UAV sampling of a 20-30-ppbv gradient in the first $200 \mathrm{~m} \mathrm{AGL}$, the suite of CBBT observations (Gronoff et al. 2019) will be used to characterize the influence of ship-based emissions aloft and at the surface, adding a more complete understanding of the chemical influences within the region.

Connecting the upper and lower Chesapeake Bay with $R / V$ SERC. To better characterize emission gradients and boundary layer heights over the water, shipborne measurements of trace gases and aerosol backscatter profiles were conducted from the R/V SERC during its transit from the upper Bay to the lower part of the estuary and especially within the lower Chesapeake Bay (cruise path in Fig. 1). On 17 and 18 July, the R/V SERC was deployed and equipped with in situ $\mathrm{O}_{3}$ and $\mathrm{NO}_{2}$ analyzers, a ceilometer, and a Pandora spectrometer. Strong spatiotemporal variability was measured for both surface $\mathrm{O}_{3}$ (Fig. 7) and $\mathrm{NO}_{2}$, reflecting changes in local air 
quality conditions. Peak $\mathrm{O}_{3}$ concentrations near 70 ppbv were recorded as the vessel approached the CBBT site near $1430 \mathrm{LT}$, providing direct evidence of a polluted overwater $\mathrm{O}_{3}$ reservoir. Total-column amounts of $\mathrm{O}_{3}$ and $\mathrm{NO}_{2}$ were also highly variable because of both changes in air quality as well as larger-scale meteorological patterns affecting $\mathrm{O}_{3}$ dynamics at higher altitudes (Tzortziou et al. 2018). The R/V SERC transected the water region between CBBT and LaRC multiple times on these days, yielding additional overwater data not possible through other means.

Pollution composition sampling with the NASA C-23 Sherpa. On 19 and 20 July, the NASA C-23 Sherpa aircraft conducted two flights over the OWLETS domain, providing in situ chemistry measurements to characterize tropospheric composition and validate retrievals of near-surface trace gases. The aircraft included a diverse chemical sensor suite (Table 1) and performed a flight pattern that included spirals over LaRC and CBBT and low-altitude passes from land to water. The objectives of the Sherpa flights included mapping land-water pollution gradients, characterizing vertical structure for validation and comparison with ground-based remote sensing observations, and sampling regionally relevant anthropogenic emission sources.

Measurements from 1214 to 1218 LT 20 July during a transect at $300 \mathrm{~m}$ AGL are presented for $\mathrm{O}_{3}$, carbon monoxide (CO), and $\mathrm{NO}_{2}$ (Fig. 8). Increases in $\mathrm{CO}$ and $\mathrm{NO}_{2}$ are linked to fossil-fuel combustion and industrial power plants. $\mathrm{NO}_{2}$ and other oxides of nitrogen are directly emitted into the atmosphere or deposited near coastlines (Loughner et al. 2016) and can quickly react in the presence of sunlight to form $\mathrm{O}_{3}$. Over the water, median $\mathrm{O}_{3}$ concentrations are near 90 ppbv, with peak concentrations occurring above 100 ppbv. Median concentrations reduce by $26 \%$ ( $18.8 \mathrm{ppbv}$ ) rapidly over a distance of $<100 \mathrm{~m}$ as the aircraft transitions from over water to over land. This transition region is also associated with decreases in pollutant loading in $\mathrm{CO}(-5.4 \%,-9.6 \mathrm{ppbv})$ and $\mathrm{NO}_{2}(-32.7 \%$, $-0.3 \mathrm{ppbv})$. This indicates the aircraft sampled two different air masses, with different chemical signatures and ages, separated distinctly at the land-water interface. Large $\mathrm{O}_{3}$ gradients observed from the Sherpa from land to water and the extensive suite of chemistry measurements [including a full suite of volatile organic compounds (VOCs)] will provide useful insights in understanding the coastal transition zone and the
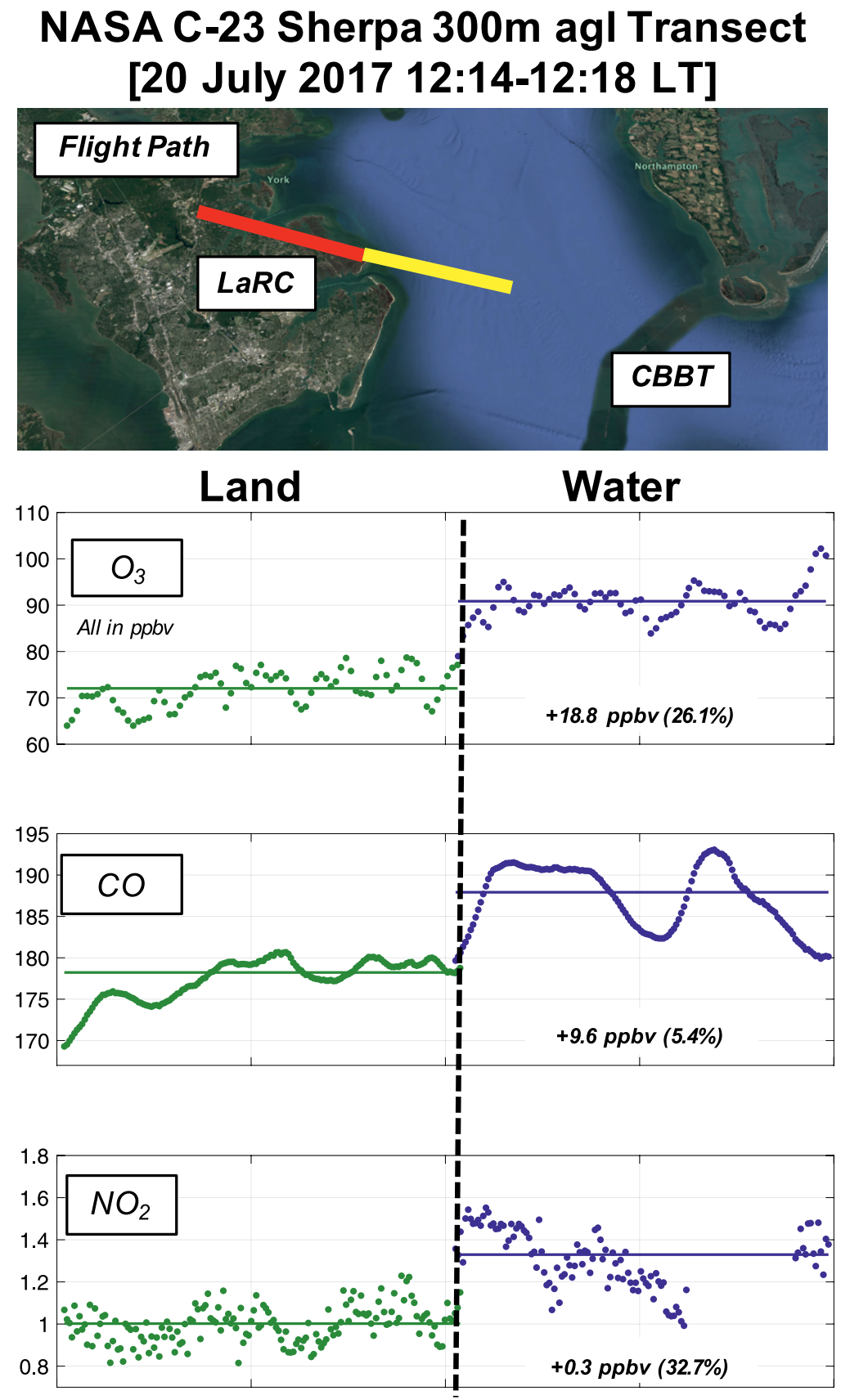

FIG. 8. NASA C-23 Sherpa sampling land-water chemical transitions near $1215 \mathrm{LT} 20 \mathrm{Jul}$ at $300 \mathrm{~m} \mathrm{AGL}$ of $\mathrm{O}_{3}, \mathrm{CO}$, and $\mathrm{NO}_{2}$. 
role of emissions, meteorology, and regional transport during the study period.

KEY FINDINGS. The OWLETS measurements captured the evolution of $\mathrm{O}_{3}$ in the horizontal and vertical domains as well as demonstrated a novel approach to characterize land-water gradients. Key findings are categorized in three main themes.

OWLETS observations unambiguously confirm the existence of the following:
1) Pollution gradients directly at the land-water interface. Observations captured significant differences in surface (horizontal) and vertical measurements over extremely short distances $(<100 \mathrm{~m})$ from land to water. These differences are clearly evident in the $\mathrm{O}_{3}$ lidar profiles from the LaRC and CBBT sites (Fig. 3), mobile car horizontal cross sections from land to water (Fig. 5), aircraft low-altitude passes from water to land (Fig. 8), and static site measurements.

\section{UNDERSTANDING POLLUTION TRANSPORT WITH PANDORA}

$\mathrm{T}$

he NASA GSFC Pandora spectrometer system retrieves total-column trace-gas densities utilizing sun-/lunarviewing and sky-scanning techniques. Validated, near-real-time data products include total-column $\mathrm{O}_{3}$ and $\mathrm{NO}_{2}$. Other, currently experimental data products include near-surface $\mathrm{O}_{3}$ and totalcolumn $\mathrm{CH}_{2} \mathrm{O}$ and $\mathrm{SO}_{2}$, with continued development of retrieval algorithms for their verification. The addition of these products will greatly widen the use case of Pandora and benefit its user community for continued monitoring of air quality and atmospheric composition. Further, current and future deployments of Pandora are focused on long-term observations in support of validation for emission and air quality-monitoring satellite platforms such as the Aura-based Ozone Monitoring Instrument (OMI; Herman et al. 2009; Lamsal et al. 2014; Kollonige et al. 2017), the Sentinel-5 Precursor TROPOMI instrument, and the upcoming TEMPO geostationary satellites.

As the number of long-term monitoring and field study deployments of Pandora continue to increase, the need for standardization has become integral to the continued utilization of Pandora. This need is being met by the Pandonia Global Network (PGN), which is a collaborative initiative between NASA and ESA on the operation of worldwide network of Pandora systems currently deployed (http://pandonia.net). PGN is supported by operating partners at NASA and the ESA.

To augment surface and airborne sampling of trace gases, Pandora spectrometer systems were deployed at several key sites (including on board the R/V SERC) during the OWLETS campaign. Pandora is useful in the monitoring of air quality because of its ability to sample column pollutants at high temporal resolution (every minute) and its sensitivity to boundary layer $\mathrm{NO}_{2}$ over short time scales (Knepp et al. 20I5). For example, during OWLETS, enhanced $\mathrm{NO}_{2}$ events were identified from the emissions of large vessels sailing through the CBBT (Gronoff et al. 2019). A time series (Fig. SBI) of Pandora column $\mathrm{NO}_{2}$ amount in Dobson units (DU; I DU $=2.69 \times 10^{16}$ molecules $\mathrm{cm}^{-2}$ ) from the CBBT site indicates a near doubling during the passage of a ship vessel shortly after I300 LT I August 2017. The impacts of these shipping emissions are a growing concern worldwide for the air quality community, and our understanding of them benefits from the OWLETS approach of coincident ground-based observations (including lidar and UAV). Combined with information from ancillary instrumentation, Pandora is helping to answer questions about the effects that these emission sources and events have on the local environment.

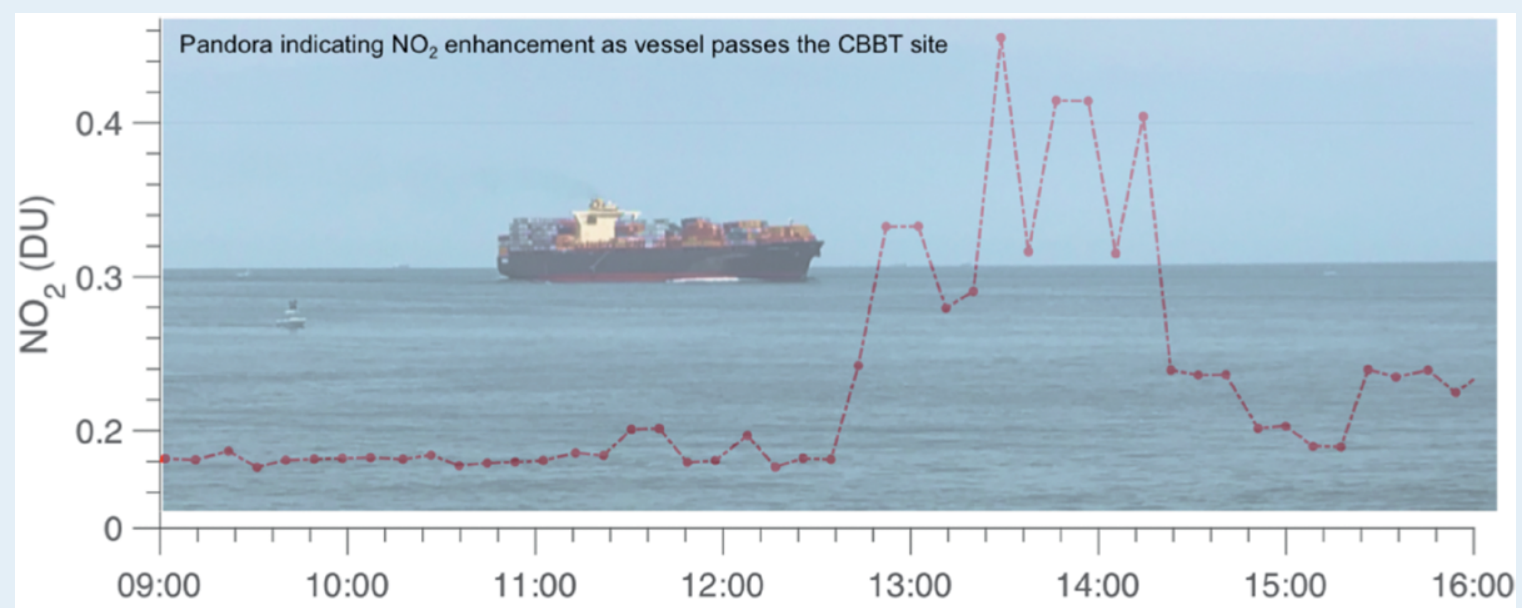

FIG. SBI. Pandora indicating a near doubling of column $\mathrm{NO}_{2}$ as shipping vessel passes the CBBT site on 01 Aug 2017. 
2) A polluted $\mathrm{O}_{3}$ reservoir over water. Observations captured elevated $\mathrm{O}_{3}$ over water (at the surface and aloft) with respect to land typically occurring when $\mathrm{O}_{3}$ levels are at their initial peak in the afternoon. The NOAA NAQFC proved able to properly forecast key transport patterns of the polluted reservoir during the 21 July pollution event.

3) Pollution variability driven by ship-based emissions. Observations have identified a high degree of overwater spatial variability in $\mathrm{O}_{3}$ and $\mathrm{NO}_{2}$ concentrations in the presence of shipping channels. This is evident from UAV (Fig. 6), Sherpa, and R/V SERC (Fig. 8) measurements.

CONCLUSIONS. The framework for the OWLETS prototype to investigate the interactions between emissions/pollutants and the complex coastline has been described in detail. This investigation and technology demonstration stemmed from the lack of historical measurements directly over water as compared to those over land, particularly in the vertical domain. For this reason, a unique suite of state, federal, and university resources (e.g., lidar, aircraft- and shipbased observations, passive sensors, surface analyzers, UAV, mobile units, and balloonborne instrumentation) were deployed during OWLETS to better understand transport and chemical gradients throughout the Chesapeake Bay. With additional interest, the project resulted in a leveraging effect that extended measurements, which dramatically enhanced the quantity and quality of observations. The synergistic approach with high-resolution vertical profiles at static sites, being linked by mobile sampling, added a multidimensional view of pollution transport in coastal regions that can be examined with limited resources. By increasing overlap periods between instruments, and specifically targeting pollution events based on operational NAQFC forecasts, the value of these datasets has increased for cross-validation and model evaluation. With many partners, data analyses will ultimately contribute to improvements in forecast models and related satellite-derived air quality data products. With more stringent regulatory policies for pollution, it is becoming increasingly imperative to completely characterize air quality episodes and verify forecasts and evaluate satellite products-OWLETS has provided a novel dataset for this purpose.

ACKNOWLEDGMENTS. This work was supported by the 2017 NASA Science Innovation Fund. The authors gratefully acknowledge support provided by the NASA Tropospheric Composition Program, the TEMPO Student Collaboration Project (supported by NASA Earth System
Science Pathfinder Program), the NASA GSFC Pandora Project, the NASA AERONet Project, and the pilots/captains and crew of the LaRC B200, WFF C-23 Sherpa, and R/V SERC. Thanks for the continued support and guidance from the Tropospheric Ozone Lidar Network (TOLNet). Gracious support was also provided from the EPA's Air, Climate, and Energy Research Program. Additional support was provided by NASA Grant NNX15AB84G. Ceilometer equipment and support were also provided by Ricardo Sakai, Ruben Delgado, and Belay Demoz. Near-real-time processing of the Pandora data was provided by Alexander Cede, Martin Tiefengraber, Moritz Mueller, Axel Kreuter, and Christian Posch. The OWLETS team would also like to thank the NOAA Environmental Modeling Center (EMC) and the NOAA Air Resources Laboratory (ARL) for guidance and support of operational forecasting, with a special thanks to Jeff McQueen and Pius Lee. We would like to extend our gratitude toward Alexander Dimov, Peter Pantina, and Nader Abuhassan for their commitment to ground site installation. The authors also acknowledge the support of Dr. Vickie Connors and the VCU Rice Center staff. Additional measurements and data processing for the C-23 Sherpa were provided by Donald Blake, Barbara Barletta, Thomas F. Hanisco, Jason St. Clair, Reem Hannun, Jessica Munyan, Natasha Dacic, Melissa Yang, and Michael Shook.

Thanks to Daniel Salkovitz, Kristen Stumpf, John Brandt, and Charles Turner for air quality forecasting and air quality monitoring assistance from the Virginia Department of Environmental Quality. Thanks to continued support from Dan Summers and the Virginia Living Museum (VLM), especially for coordinating access and installment of a monitor at the VLM during and beyond the study period. Special thanks to an exceptional group of student interns: Lance Nino, Betsy Farris, Lindsey Rodio, Jeremy Schroeder, Pablo Sanchez, Emily Gargulinski, Marlia Harnden, Desorae Davis, Angela Atwater, Owen Parker, Julio Roman, Joseph Robinson, Lena Shalaby, Ian Fenn, Sahil Banyopadhyay, Amanda Engel, Faran Haider, Weston Millar, Fayzan Saleem, Hakeen Bisyir, Nyle Rodgers, Vicky Baker, Sunglee Choi, Nash Kocur, Brett Poche, and Nabil Nowak. Thanks to Ed Adcock, Zak Johns, Mark Motter, Jim Neilan, and Matt Vaughan of the NASA LaRC UAV team. This work could also not have been completed without the thoughtful accommodations of Edward Spencer and all of the management and employees with the Chesapeake Bay Bridge and Tunnel District.

Unless otherwise noted, all data from the OWLETS campaign and those used in this manuscript have been uploaded to an archive web interface (www-air.larc.nasa .gov/missions/owlets). Additional field reports, flight forecasts, presentations, and other information to facilitate use of OWLETS data by the research community at large. NAQFC archive and verification plots are available 
through the NOAA Environmental Modeling Center (EMC) (at www.emc.ncep.noaa.gov/mmb/aq/cmaq/web $/ \mathrm{html} / \mathrm{max} . \mathrm{html}$ ) and have real-time official dissemination via NOAA Air Resources Laboratory (ARL) (at http:// airquality.weather.gov/).

\section{REFERENCES}

Barletta, B., and Coauthors, 2017: Characterization of carbon monoxide, methane and nonmethane hydrocarbons in emerging cities of Saudi Arabia and Pakistan and in Singapore. J. Atmos. Chem., 74, 87-113, https://doi.org/10.1007/s10874-016-9343-7.

Berkoff, T. A., E. J. Welton, J. R. Campbell, S. Valencia, J. D. Spinhirne, S. C. Tsay, and B. N. Holben, 2004: Observations of aerosols using the Micro-Pulse Lidar Network (MPLNET). Proc. Geoscience and Remote Sensing Symp., Anchorage, AK, Institute of Electrical and Electronics Engineers, 2208-2211, https:/doi .org/10.1109/IGARSS.2004.1370799.

Blaylock, B. K., J. D. Horel, and E. T. Crosman, 2017: Impact of lake breezes on summer ozone concentrations in the Salt Lake valley. J. Appl. Meteor. Climatol., 56, 353-370, https://doi.org/10.1175 /JAMC-D-16-0216.1.

Chai, T., and Coauthors, 2013: Evaluation of the United States National Air Quality Forecast Capability experimental real-time predictions in 2010 using Air Quality System ozone and $\mathrm{NO}_{2}$ measurements. Geosci. Model Dev., 6, 1831-1850, https://doi .org/10.5194/gmd-6-1831-2013.

Crawford, J. H., and K. E. Pickering, 2014: DISCOVER-AQ: Advancing strategies for air quality observations in the next decade. EM Magazine, Vol. 64, No. 9, Air and Waste Management Association, Pittsburgh, PA, 4-7.

Daum, P. H., L. I. Kleinman, S. R. Springston, L. J. Nunnermacker, Y. N. Lee, J. Weinstein-Lloyd, J. Zheng, and C. M. Berkowitz, 2004: Origin and properties of plumes of high ozone observed during the Texas 2000 Air Quality Study (TexAQS 2000). J. Geophys. Res., 109, D17306, https://doi .org/10.1029/2003JD004311.

De Young, R., W. Carrion, R. Ganoe, D. Pliutau, G. Gronoff, T. Berkoff, and S. Kuang, 2017: Langley mobile ozone lidar: Ozone and aerosol atmospheric profiling for air quality research. Appl. Opt., 56, 721-730, https://doi.org/10.1364/AO.56.000721.

Dreessen, J., J. Sullivan, and R. Delgado, 2016: Observations and impacts of transported Canadian wildfire smoke on ozone and aerosol air quality in the Maryland region on June 9-12, 2015. J. Air Waste Manage. Assoc., 66, 842-862, https://doi.org/10.1080 /10962247.2016.1161674.
Dye, T. S., P. T. Roberts, and M. E. Korc, 1995: Observations of transport processes for ozone and ozone precursors during the 1991 Lake Michigan ozone study. J. Appl. Meteor., 34, 1877-1889, https://doi .org/10.1175/1520-0450(1995)034<1877:OOTPFO $>2.0 . \mathrm{CO} ; 2$.

Farris, B. M., G. P. Gronoff, W. Carrion, T. Knepp, M. Pippin, and T. A. Berkoff, 2018: Demonstration of an off-axis parabolic receiver for near-range retrieval of lidar ozone profiles. Atmos. Meas. Tech. Discuss., https://doi.org/10.5194/amt-2018-178.

Garner, G. G., A. M. Thompson, P. Lee, and D. K. Martins, 2015: Evaluation of NAQFC model performance in forecasting surface ozone during the 2011 DISCOVER-AQ campaign. J. Atmos. Chem., 72, 483-501, https://doi.org/10.1007/s10874-013-9251-z. Goldberg, D. L., C. P. Loughner, M. Tzortziou, J. W. Stehr, K. E. Pickering, L. T. Marufu, and R. R. Dickerson, 2014: Higher surface ozone concentrations over the Chesapeake Bay than over the adjacent land: Observations and models from the DISCOVER-AQ and CBODAQ campaigns. Atmos. Environ., 84, 9-19, https://doi.org/10.1016/j.atmosenv.2013.11.008.

Granados-Muñoz, M. J., and T. Leblanc, 2016: Tropospheric ozone seasonal and long-term variability as seen by lidar and surface measurements at the JPL-Table Mountain facility, California. Atmos. Chem. Phys., 16, 9299-9319, https://doi.org/10.5194 lacp-16-9299-2016.

-, M. S. Johnson, and T. Leblanc, 2017: Influence of the North American monsoon on Southern California tropospheric ozone levels during summer in 2013 and 2014. Geophys. Res. Lett., 44, 6431-6439, https:// doi.org/10.1002/2017GL073375.

Gronoff, G., and Coauthors, 2019: A method for observing near range point source induced $\mathrm{O}_{3}$ titration events using co-located lidar and pandora measurements. Atmos. Environ., in press.

Herman, J., A. Cede, E. Spinei, G. Mount, M. Tzortziou, and N. Abuhassan, 2009: $\mathrm{NO}_{2}$ column amounts from ground-based Pandora and MFDOAS spectrometers using the direct-sun DOAS technique: Intercomparisons and application to OMI validation. J. Geophys. Res., 114, D13307, https://doi .org/10.1029/2009JD011848.

Holben, B. N., and Coauthors, 1998: AERONET-A federated instrument network and data archive for aerosol characterization. Remote Sens. Environ., 66, 1-16, https://doi.org/10.1016/S0034-4257(98)00031-5. Johnson, M. S., S. Kuang, L. Wang, and M. J. Newchurch, 2016: Evaluating summer-time ozone enhancement events in the southeast United States. Atmosphere, 7, 108, https://doi.org/10.3390/atmos7080108. 
— X. Xiu, P. Zoogman, J. Sullivan, M. J. Newchurch, S. Kuang, T. Leblanc, and T. McGee, 2018: Potential sources of a priori ozone profiles for TEMPO tropospheric ozone retrievals. Atmos. Meas. Tech., 11, 3457-3477, https://doi.org/10.5194/amt-11-3457-2018.

Knepp, T., and Coauthors, 2015: Estimating surface $\mathrm{NO}_{2}$ and $\mathrm{SO}_{2}$ mixing ratios from fast-response total column observations and potential application to geostationary missions. J. Atmos. Chem., 72, 261-286, https://doi.org/10.1007/s10874-013-9257-6.

Kollonige, D. E., and Coauthors, 2017: OMI satellite and ground-based Pandora observations and their application to surface $\mathrm{NO}_{2}$ estimations at terrestrial and marine sites. J. Geophys. Res. Atmos., 123, 1441-1459, https://doi.org/10.1002/2017JD026518.

Kuang, S., and Coauthors, 2017: Summertime tropospheric ozone enhancement associated with a cold front passage due to stratosphere-to-troposphere transport and biomass burning: Simultaneous ground-based lidar and airborne measurements. J. Geophys. Res. Atmos., 122, 1293-1311, https://doi .org/10.1002/2016JD026078.

Lamsal, L. N., and Coauthors, 2014: Evaluation of OMI operational standard $\mathrm{NO}_{2}$ column retrievals using in-situ and surface-based $\mathrm{NO}_{2}$ observations. Atmos. Chem. Phys., 14, 112587-112609, https://doi .org/10.5194/acp-14-11587-2014.

Langford, A. O., and Coauthors, 2017: Entrainment of stratospheric air and Asian pollution by the convective boundary layer in the southwestern US. J. Geophys. Res. Atmos., 122, 1312-1337, https://doi .org/10.1002/2016JD025987.

— stratospheric intrusions and transported pollution by the Tropospheric Ozone Lidar Network (TOLNet) and NASA Alpha Jet Experiment (AJAX): Observations and comparison to HYSPLIT, RAQMS, and FLEXPART. Atmos. Environ., 174, 1-14, https://doi .org/10.1016/j.atmosenv.2017.11.031.

Leblanc, T., and Coauthors, 2018: Validation of the TOLNet lidars: the Southern California Ozone Observation Project (SCOOP). Atmos. Meas. Tech., 11, 6137-6162, https://doi.org/10.5194/amt-11-6137-2018.

Loughner, C. P., D. J. Allen, K. E. Pickering, D. L. Zhang, Y. X. Shou, and R. R. Dickerson, 2011: Impact of fair-weather cumulus clouds and the Chesapeake Bay breeze on pollutant transport and transformation. Atmos. Environ., 45, 4060-4072, https://doi .org/10.1016/j.atmosenv.2011.04.003.

— , and Coauthors, 2014: Impact of bay-breeze circulations on surface air quality and boundary layer export. J. Appl. Meteor. Climatol., 53, 1697-1713, https://doi.org/10.1175/JAMC-D-13-0323.1.
— M. Mzortziou, S. Shroder, and K. E. Pickering, 2016: Enhanced dry deposition of nitrogen pollution near coastlines: A case study covering the Chesapeake Bay estuary and Atlantic Ocean coastline. J. Geophys. Res. Atmos., 121, 14 221-14238, https://doi.org/10.1002 /2016JD025571.

Martins, D. K., R. M. Stauffer, A. M. Thompson, T. N. Knepp, and M. Pippin, 2012: Surface ozone at a coastal suburban site in 2009 and 2010: Relationships to chemical and meteorological processes. $J$. Geophys. Res., 117, D05306, https://doi.org/10.1029 /2011JD016828.

Mazzuca, G. M., K. E. Pickering, R. D. Clark, C. P. Loughner, A. Fried, D. C. S. Zweers, A. J. Weinheimer, and R. R. Dickerson, 2017: Use of tethersonde and aircraft profiles to study the impact of mesoscale and microscale meteorology on air quality. Atmos. Environ., 149, 55-69, https://doi.org/10.1016/j .atmosenv.2016.10.025.

Nowlan, C. R., and Coauthors, 2016: Nitrogen dioxide observations from the Geostationary Trace gas and Aerosol Sensor Optimization (GeoTASO) airborne instrument: Retrieval algorithm and measurements during DISCOVER-AQ Texas 2013. Atmos. Meas. Tech., 9, 2647-2668, https://doi.org/10.5194/amt-9 -2647-2016.

Pollack, I. B., B. M. Lerner, and T. B. Ryerson, 2010: Evaluation of ultraviolet light-emitting diodes for detection of atmospheric $\mathrm{NO}_{2}$ by photolysis-chemiluminescence. J. Atmos. Chem., 65, 111-125, https:// doi.org/10.1007/s10874-011-9184-3.

Ridley, B. A., and F. E. Grahek, 1990: A small, low flow, high sensitivity reaction vessel for $\mathrm{NO}$ chemiluminescence detectors. J. Atmos. Oceanic Technol., 7, 307-311, https://doi.org/10.1175/1520 -0426(1990)007<0307:ASLFHS>2.0.CO;2.

Ring, A. M., and Coauthors, 2018: Evaluating commercial marine emissions and their role in air quality policy using observations and the CMAQ model. Atmos. Environ., 173, 96-107, https://doi .org/10.1016/j.atmosenv.2017.10.037.

Senff, C. J., and Coauthors, 2016: Using ozone lidar to investigate sources of high ozone concentrations in the western United States. 27th Int. Laser Radar Conf., New York, NY, National Oceanic and Atmospheric Administration, 20005, https://doi.org/10.1051 lepjconf/201611920005.

Shafran, P. C., N. L. Seaman, and G. A. Gayno, 2000: Evaluation of numerical predictions of boundary layer structure during the Lake Michigan ozone study. J. Appl. Meteor., 39, 412-426, https://doi .org/10.1175/1520-0450(2000)039<0412:EONPOB $>2.0 . \mathrm{CO} ; 2$. 
Stauffer, R. M., and A. M. Thompson, 2015: Bay breeze climatology at two sites along the Chesapeake Bay from 1986-2010: Implications for surface ozone. J. Atmos. Chem., 72, 355-372, https://doi.org/10.1007 /s10874-013-9260-y.

— surface ozone at Edgewood, MD during July 2011. J. Atmos. Chem., 72, 335-353, https://doi.org/10.1007 /s10874-012-9241-6.

St. Clair, J. M., A. K. Swanson, S. A. Bailey, G. M. Wolfe, J. E. Marrero, L. T. Iraci, J. G. Hagopian, and T. F. Hanisco, 2017: A new non-resonant laser-induced fluorescence instrument for the airborne in situ measurement of formaldehyde. Atmos. Meas. Tech., 10, 4833-4844, https://doi.org/10.5194/amt-10-4833-2017.

Strawbridge, K. B., B. J. Firanski, and M. S. Travis, 2017: Autonomous ozone, aerosol, and water vapor profiling of the atmosphere. SPIE Newsroom, 9 May, https://doi.org/10.1117/2.1201702.006870.

Sullivan, J. T., T. J. McGee, G. K. Sumnicht, L. W. Twigg, and R. M. Hoff, 2014: A mobile differential absorption lidar to measure sub-hourly fluctuation of tropospheric ozone profiles in the Baltimore-Washington, DC region. Atmos. Meas. Tech., 7, 3529-3548, https:// doi.org/10.5194/amt-7-3529-2014.

Sullivan, J. T., T. J. McGee1, T. Leblanc, G. K. Sumnicht, and L. W. Twigg, 2015a: Optimization of the GSFC TROPOZ DIAL retrieval using synthetic lidar returns and ozonesondes - Part 1: Algorithm validation. Atmos. Meas. Tech., 8, 4133-4143, https://doi. org/10.5194/amt-8-4133-2015.

,-- , R. DeYoung, L. W. Twigg, G. K. Sumnicht, D. Pliutau, T. Knepp, and W. Carrion, 2015b: Results from the NASA GSFC and LaRC ozone lidar intercomparison: New mobile tools for atmospheric research. J. Atmos. Oceanic Technol., 32, 1779-1795, https://doi.org/10.1175/JTECH-D-14-00193.1.

,-- , A. M. Thompson, R. B. Pierce, G. K. Sumnicht, L. W. Twigg, E. Eloranta, and R. M. Hoff, 2015c: Characterizing the lifetime and occurrence of stratospheric-tropospheric exchange events in the Rocky Mountain region using highresolution ozone measurements. J. Geophys. Res. Atmos., 120, 12 410-12 424, https://doi.org/10.1002 /2015JD023877.

— - and Coauthors, 2016: Quantifying the contribution of thermally driven recirculation to a high-ozone event along the Colorado Front Range using lidar. J. Geophys. Res. Atmos., 121, 10377-10390, https:/doi .org/10.1002/2016JD025229.

—, S. D. Rabenhorst, J. Dreessen, T. J. McGee, R. Delgado, L. Twigg, and G. Sumnicht, 2017: Lidar observations revealing transport of $\mathrm{O}_{3}$ in the presence of a nocturnal low-level jet: Regional implications for "next-day" pollution. Atmos. Environ., 158, 160-171, https://doi.org/10.1016/j.atmosenv.2017.03 .039 .

Thompson, A. M., R. M. Stauffer, S. K. Miller, D. K. Martins, E. Joseph, A. J. Weinheimer, and G. S. Diskin, 2015: Ozone profiles in the BaltimoreWashington region (2006-2011): Satellite comparisons and DISCOVER-AQ observations. J. Atmos. Chem., 72, 393-422, https://doi.org/10.1007/s10874 -014-9283-z.

Tong, D. Q., and Coauthors, 2015: Long-term $\mathrm{NO}_{\mathrm{x}}$ trends over large cities in the United States during the great recession: Comparison of satellite retrievals, ground observations, and emission inventories. Atmos. Environ., 107, 70-84, https://doi.org/10.1016/j .atmosenv.2015.01.035.

Tzortziou, M., J. R. Herman, A. Cede, and N. Abuhassan, 2012: High precision, absolute total column ozone measurements from the Pandora spectrometer system: Comparisons with data from a Brewer double monochromator and Aura OMI. J. Geophys. Res., 117, D16303, https://doi.org/10.1029/2012JD017814.

,,--- C. P. Loughner, N. Abuhassan, and S. Naik, 2015: Spatial and temporal variability of ozone and nitrogen dioxide over a major urban estuarine ecosystem. J. Atmos. Chem., 72, 287-309, https://doi .org/10.1007/s10874-013-9255-8.

, O. Parker, B. Lamb, J. R. Herman, L. Lamsal, R. Stauffer, and N. Abuhassan 2018: Atmospheric Trace Gas $\left(\mathrm{NO}_{2}\right.$ and $\left.\mathrm{O}_{3}\right)$ Variability in South Korean Coastal Waters, and Implications for Remote Sensing of Coastal Ocean Color Dynamics. Remote Sens., 10, 1587, https://doi.org/10.3390/rs10101587.

Wang, L., M. J. Newchurch, A. Pour-Biazar, S. Kuang, M. Khan, X. Liu, W. Koshak, and K. Chance, 2013: Estimating the influence of lightning on upper tropospheric ozone using NLDN lightning data and CMAQ model. Atmos. Environ., 67, 219-228, https:// doi.org/10.1016/j.atmosenv.2012.11.001.

—_ and Coauthors, 2017: Quantifying TOLNet ozone lidar accuracy during the 2014 DISCOVER-AQ and FRAPPÉ campaigns. Atmos. Meas. Tech., 10, 38653876, https://doi.org/10.5194/amt-10-3865-2017.

Wolfe, G. M., and Coauthors, 2018: The NASA Carbon Airborne Flux Experiment (CARAFE): Instrumentation and methodology. Atmos. Meas. Tech., 11, 1757-1776, https://doi.org/10.5194/amt-11-1757 -2018 .

Zoogman, P., and Coauthors, 2017: Tropospheric Emissions: Monitoring of Pollution (TEMPO). J. Quant. Spectrosc. Radiat. Transf., 186, 17-39, https://doi .org/10.1016/j.jqsrt.2016.05.008. 